\title{
A Study to Assess the Effectiveness of Self-Instructional M odule on Home Management of Diarrhea among M others of Under Five Children in Selected Hospital at Bangalore
}

\section{Nirmali Gogoi.}

Assistant Professor, Department of Child Health Nursing, Sankar M adhab College of Nursing, Assam down town University, Guwahati, Assam, India.

\section{ABSTRACT}

Background: Diarrhea is a symptom of a variety of conditions and it constitutes one of the main causes of morbidity and mortality among infants and children throughout the world. In India $15 \%$ of total population under five children. $50 \%$ of all deaths occur below 5 years of age in India. In India alone, nearly 1.5 million children die due to acute diarrhea every year.

Aim: To assess the effectiveness of Self- instructional module on home management of diarrhea among mothers of under five children in selected hospital, at Bangalore

M aterials and M ethods: Pre experimental one group pre-test post -test design used to measure the knowledge of the mothers of underfive children regarding home management of the diarrhea with application of the SelfInstructional Module.

Results: The overall mean knowledge score of pre-test and post- test, which reveals the post- test mean knowledge score was higher $(72.6 \%$ ) with standard deviation $\pm 10.2 \%$ when compared with pre- test mean knowledge score value which was $(46.8 \%)$ with standard deviation $\pm 17.3 \%$.

The statistical paired't' test implies that the difference in the pre- test and post- test knowledge score found statistically significant at $5 \%$ level. The post-test mean knowledge difference was $25.8 \%$ with a paired' $t$ ' value of 15.69 .

Conclusion: Diarrhea is a preventable disease. M other's knowledge regarding home management of diarrhea is most important preventable aspect of diarrhea. Lack of knowledge of mother on diarrhea management is a major hindrance to prevent and control of diarrhea in children.

KEY WORDS: Diarrhea, M other of under five children, Home management, Self-Instructional M odule.

Address for correspondence: Mrs Nirmali Gogoi, Assistant Professor, Department of Child Health Nursing, Sankar M adhab College of Nursing, Assam down town University, Guwahati, Assam, India.

E-Mail: nirmali.gogoi111@gmail.com

\begin{tabular}{|c|c|c|}
\hline \multicolumn{3}{|c|}{ Online Access and Article Informtaion } \\
\hline \multirow{2}{*}{$\begin{array}{c}\text { Quick Response code } \\
\text { Dol: } 10.16965 \text { /ijims.2016.146 }\end{array}$} & \multicolumn{2}{|c|}{$\begin{array}{l}\text { International Journal of Integrative Medical Sciences } \\
\text { www.imedsciences.com }\end{array}$} \\
\hline & $\begin{array}{l}\text { Received: 12-08-2016 } \\
\text { Reviewed: 12-08-2016 }\end{array}$ & $\begin{array}{l}\text { Accepted: 22-08-2016 } \\
\text { Published: 31-08-2016 }\end{array}$ \\
\hline Source of Funding: Self & \multicolumn{2}{|c|}{ Conflicts of interest: None } \\
\hline
\end{tabular}

\section{BACKGROUND}

Worldwide, particularly in developing countries, diarrheal diseases still constitute significant causes of mortality and morbidity [1]. WHO reported, 5.9 million children under age five died in 2015, 16000 everyday [2]. The WHO estimates that between 90,000 and 153,000 children die from rotavirus infection in India each year.
According to UNICEF, diarrhea is a leading killer of children, accounting for 9 percent of all deaths among children under age 5 worldwide in 2015 [3]. In India $15 \%$ of total population under five children. $50 \%$ of all deaths occur below 5 years of age in India.

It is estimated that $20 \%$ of all hospitalization of 
children due to diarrheal diseases. In India alone, nearly 1.5 million children die due to acute diarrhea every year [4]. Diarrhea is the third leading cause of childhood mortality in India, and is responsible for $13 \%$ of all deaths/year in children under 5years of age [5]. In 2011 UNICEF under-five mortality rate for India is 61 per 1000 live births. The MDS (Million Death Study) estimates the proportionate mortality rate in India due to diarrhea in $\varangle$ years children to be 13.2\% [6]. In Karnataka, A survey study was reported that mortality due to diarrhea was 1.8 per 100 episodes [7]. In the Kaveri basin of Karnataka state, diarrhea associated deaths were $31.9 \%$, accounting for nearly one-third of total deaths among under five [8].

A study, conducted in Ahmedabad was reported diarrhea disease were responsible for $7.69 \%$ deaths in under five children [9]. Diarrhea is a major cause of malnutrition in children. Lack of clean water, crowding, poor hygiene, nutritional deficiency and poor sanitation are major risk factors [10]. Dehydration is the most common life threatening consequence of diarrhea. Severe dehydration can cause death [11]. A study reported that dehydration causes over 1.5 million deaths a year [12]. Hand washing is the major preventive measure of diarrhea [13].

The major factor associated with adequate home treatment was the mother's knowledge about the causes and treatment of diarrhea [14]. Educational status of mother showed a positive correlation with the incidence of diarrheal diseases [15]. Improved feeding and practices and improved personal and domestic hygiene should be considered important intervention in reducing the high incidence of diarrhea [16]. The main objective of ORS therapy programme is to prevent diarrhea associated deaths in children due to dehydration [17]. One of the best methods of controlling diarrhea is home management and mothers are the chief caregivers for under fives. Hence their knowledge is essential for appropriate action related to home management of diarrhea.

\section{MATERIALS AND METHODS}

A pre-experimental and evaluative research approach was used with one group pre-test post-test design to evaluate the effectiveness of the SIM. The study was conducted in under five clinic of K.C General Hospital at Bangalore. The sample composed of 40 mothers of under five children. A purposive sampling technique was used. A structured questionnaire on home management of diarrhea was used for data collection. The questionnaire consisted of two sections: Section A-Demographic variables with 10 items. Section B-Knowledge questionn-aires consist of 41 objective type questions covering the following area.

Ethical clearance from Institutional ethical committee was obtained. The written permission was obtained from the authority prior to the data collection. The purpose of the subject was explained to them and informed consent was obtained from the respondents. A pre-test with the structured questionnaire was given on the first day, following which a copy of the SIM was given to the respondents with instruction to retain and read the SIM thoroughly and come prepared for the post -test on the 7 day. Posttest was administered by using the same questionnaire. The data collection process was terminated by thanking the respondent for their patience and cooperation.

Schematic presentation of study design.

\begin{tabular}{|c|c|c|c|}
\hline Group & Pre-test & Intervention & Post-test \\
\hline Mothers of under & Day-1 & Day-1 & Day-7 \\
five children (40) & (Dependent variable) & (Independent variable) & (Dependent variable) \\
\hline
\end{tabular}

$\mathbf{O}_{1}$ : Knowledge assessment on the first day by using structured questionnaire.

$\mathbf{O}_{2}$ : Knowledge assessment on the $7^{\text {th }}$ day by using structured questionnaire.

$\mathbf{X}:$ Administration of prepared SIM on the first day

\section{RESULTS}

Results were presented in form of number, proportions and percentages. The data obtained would be analyzed by both descriptive and inferential statistics. The descriptive statistics would be used to describe the sample characteristic in terms of frequency and percentage. Paired ' $t$ ' test is used to test the significance difference in the knowledge score between pre-test and post-test performance. Association measured by $X^{2}$ test (Chi - square test) between pre-test and post-test with selected demographic variables.

The study shows that majority of mothers (19) 
$47 \%$ were in the age group of 27-30. M ajority of mothers (20) $65 \%$ were Hindu by religion. Maximum numbers of mothers $70 \%$ belong to joint family. Maximum numbers of mothers $50 \%$ were having high school level of education. Maximum numbers of mothers $42.5 \%$ had two children. Maximum numbers of mothers $55 \%$ were housewife. Maximum numbers of mothers $30 \%$ had monthly income of 3,001-4,000 and equal number of mothers (30\%) had 4,001-6.000. M aximum numbers of mothers $70 \%$ were from rural place. Maximum numbers of mothers $97.5 \%$ had exposure to source of information from health personnel. Maximum numbers of mothers $65 \%$ had no history of diarrhea.

Aspect wise pre-test (Table-1) and post- test (Table-2) mean knowledge scores, regarding definition, types and causes of diarrhea, the knowledge score were $38.2 \%$, and $66.8 \%$, in the aspect of sign-symptoms and complication, the knowledge score were $45.4 \%$ and $78.6 \%$, in home management of diarrhea, the knowledge score were $51.1 \%$ and $72.5 \%$, in preventive measures, the knowledge score were $52.5 \%$ and $77.5 \%$. The total mean pre-test knowledge score was $46.8 \%$ with standard deviation +17.3 and the total mean post-test knowledge score was $72.6 \%$ with standard deviation \pm 10.2 .

On frequency and percentage of pre test and post test knowledge level of mothers, it shows that the majority of mothers $70.0 \%$ had inadequate level, $30 \%$ of mothers had moderate level in the pre -test knowledge. In the post- test knowledge level, majority of mothers $57.5 \%$ had moderate and $42.5 \%$ of mothers had adequate knowledge. The $X^{2}$ values is 48.46 at the $5 \%$ level of significant. (Table 3)

Table 1: Aspect wise Pre test Mean knowledge score of mothers.

\begin{tabular}{|c|c|c|c|c|c|c|c|}
\hline \multirow{2}{*}{$\begin{array}{l}\mathrm{N} \\
\mathbf{0} .\end{array}$} & \multirow[t]{2}{*}{ Aspects } & \multirow{2}{*}{$\begin{array}{l}\text { Stateme } \\
\text { nts }\end{array}$} & \multirow{2}{*}{$\begin{array}{c}\text { Max } \\
\text { scor } \\
\text { e }\end{array}$} & \multirow{2}{*}{$\begin{array}{l}\text { Range } \\
\text { Score }\end{array}$} & \multicolumn{3}{|c|}{ Knowledge aspect } \\
\hline & & & & & Mean & $\begin{array}{c}\text { Mean } \\
(\%)\end{array}$ & $\begin{array}{l}\text { SD } \\
(\%)\end{array}$ \\
\hline I & $\begin{array}{l}\text { Definition, } \\
\text { types and }\end{array}$ & 11 & 11 & $1-10$ & 4.20 & 38.2 & 27.3 \\
\hline II & $\begin{array}{l}\text { Signs \& } \\
\text { symptoms and } \\
\text { complications }\end{array}$ & 7 & 7 & $0-7$ & 3.18 & 45.4 & 26.7 \\
\hline $\begin{array}{l}\text { II } \\
\text { I }\end{array}$ & $\begin{array}{l}\text { Home } \\
\text { management }\end{array}$ & 18 & 18 & $3-14$ & 9.20 & 51.1 & 14.7 \\
\hline \multirow[t]{2}{*}{$\begin{array}{l}\mathrm{I} \\
\mathrm{V}\end{array}$} & $\begin{array}{l}\text { Preventive } \\
\text { measures }\end{array}$ & 5 & 5 & $1-5$ & 2.63 & 52.5 & 19.0 \\
\hline & Combined & 41 & 41 & $9-33$ & 19.50 & 46.8 & 17.3 \\
\hline
\end{tabular}

Table 2: Aspect wise Post- test M ean knowledge score of mothers.

\begin{tabular}{|c|c|c|c|c|c|c|c|}
\hline \multirow{2}{*}{$\begin{array}{l}N \\
\text { o. }\end{array}$} & \multirow[t]{2}{*}{ Aspects } & \multirow{2}{*}{$\begin{array}{l}\text { Statemen } \\
\text { ts }\end{array}$} & \multirow{2}{*}{$\begin{array}{l}\text { Max. } \\
\text { score }\end{array}$} & \multirow{2}{*}{$\begin{array}{l}\text { Range } \\
\text { Score }\end{array}$} & \multicolumn{3}{|c|}{ Knowledge aspect } \\
\hline & & & & & Mean & $\begin{array}{c}\text { Mean } \\
(\%)\end{array}$ & $\begin{array}{l}\text { SD } \\
(\%)\end{array}$ \\
\hline I & $\begin{array}{l}\text { Definition, } \\
\text { types and } \\
\text { causes }\end{array}$ & 11 & 11 & $4-11$ & 7.35 & 66.8 & 18.7 \\
\hline II & $\begin{array}{l}\text { Signs \& } \\
\text { symptoms } \\
\text { and } \\
\text { complicatio }\end{array}$ & 7 & 7 & $4-7$ & 5.50 & 78.6 & 14.8 \\
\hline $\begin{array}{l}\text { II } \\
\text { I }\end{array}$ & $\begin{array}{l}\text { Home } \\
\text { managemen } \\
t\end{array}$ & 18 & 18 & $9-16$ & 13.05 & 72.5 & 11.0 \\
\hline \multirow[t]{2}{*}{$\begin{array}{l}\mathrm{I} \\
\mathrm{V}\end{array}$} & $\begin{array}{l}\text { Preventive } \\
\text { measures }\end{array}$ & 5 & 5 & $2-5$ & 3.88 & 77.5 & 14.5 \\
\hline & Combined & 41 & 41 & $25-34$ & 29.78 & 72.6 & 10.2 \\
\hline
\end{tabular}


Fig.1: Pre test and post- test mean knowledge score on home management of diarrhea.

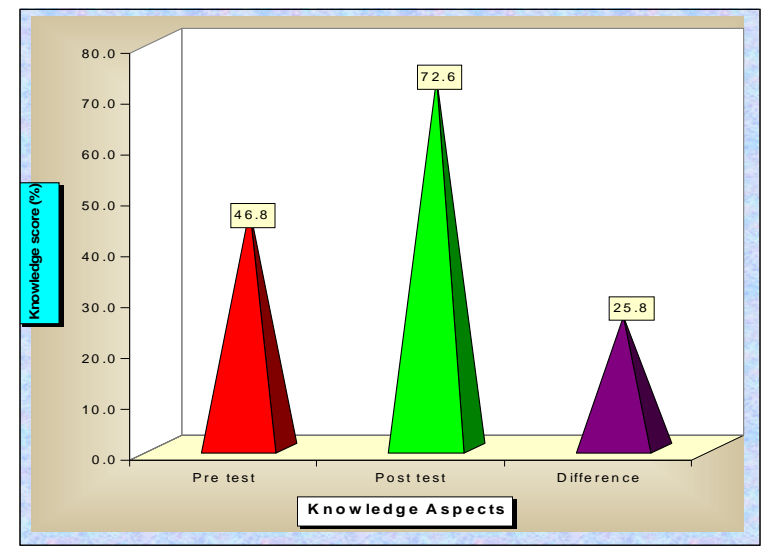

Table 3: Frequency and percentage of pre test and post test knowledge level of mothers. $n=40$.

\begin{tabular}{|c|c|c|c|c|c|}
\hline \multirow{2}{*}{$\begin{array}{c}\text { Knowledge } \\
\text { Level }\end{array}$} & \multicolumn{4}{|c|}{ Classification of Respondents } & \multirow{2}{*}{$\chi^{2}$} \\
\cline { 2 - 5 } & \multicolumn{2}{|c|}{ Pre test } & \multicolumn{2}{c|}{ Post test } & \multirow{2}{*}{ Value } \\
\cline { 2 - 5 } & Number & Percent & Number & Percent & \\
\hline $\begin{array}{c}\text { Adequate } \\
(50 \%)\end{array}$ & 28 & 70 & 0 & 0 & \\
\hline $\begin{array}{c}\text { Moderate } \\
(51-75 \%)\end{array}$ & 12 & 30 & 23 & 57.5 & \multirow{2}{*}{$48.46^{*}$} \\
\hline $\begin{array}{c}\text { Inadequate } \\
(>75 \%)\end{array}$ & 0 & 0 & 17 & 42.5 & \\
\hline Total & 40 & 100 & 40 & 100 & \\
\hline
\end{tabular}

* Significant at $5 \%$ Level, $\chi^{2}(0.05,1 \mathrm{df})=3.841$

Table 4: Mean knowledge score of Pre- test and Post test of mothers.

\begin{tabular}{|c|c|c|c|c|c|c|}
\hline \multirow[t]{2}{*}{ Aspect } & \multirow[t]{2}{*}{ Statements } & \multirow{2}{*}{$\begin{array}{l}\text { Max } \\
\text { score }\end{array}$} & \multicolumn{3}{|c|}{ Knowledge aspect } & \multirow{2}{*}{$\begin{array}{l}\text { Paired } \\
\mathrm{t} \text {-Test }\end{array}$} \\
\hline & & & Mean & Mean (\%) & $S D(\%)$ & \\
\hline Pretest & 41 & 41 & 19.50 & 46.8 & 17.3 & \\
\hline Post test & 41 & 41 & 29.78 & 72.6 & 10.2 & \\
\hline Difference & 41 & 41 & 10.58 & 25.8 & 10.4 & \\
\hline
\end{tabular}

Regarding effectiveness of SIM on knowledge of mothers regarding home management of diarrhea, the study reveals that the post- test mean knowledge score was higher $(72.6 \%)$ with standard deviation $\pm 10.2 \%$ when compared with pre- test mean knowledge score value which was $(46.8 \%)$ with standard deviation $\pm 17.3 \%$.

The statistical paired ' $\mathrm{t}$ ' test implies that the difference in the pre- test and post- test knowledge score found statistically significant at $5 \%$ level .The post-test mean knowledge difference was $25.8 \%$ with a paired ' $t$ ' value of 15.69. (Table 4)

On analyzing the association of knowledge, in pre-test with selected demographic variables, it was found that there was no significant association between the knowledge scores with selected demographic variables and in post-test with same selected demographic variables, it was found that educational status of mother $\left(X^{2}=6.70, p>0.05,2 \mathrm{df}\right)$ and place of residence is statistically significant $\left(X^{2}=4.68, p>0.05,1 d f\right)$ with knowledge score.

\section{DISCUSSION}

The present study was aimed to assess the effectiveness of the self-instructional module on knowledge of mothers regarding home management of diarrhea.

The study was conducted in the under five clinic of K.C general Hospital at Bangalore. A structured self-administered questionnaire selected on the basis of the objective of the study was considered to be most appropriate instrument for assessing the level of knowledge regarding home management of diarrhea. A self-instructional module was administered to the subjects after the pre test before which the post-test was conducted. Purposive sampling technique was used to select 40 mothers of under five children. The study revealed that the majority of mothers $70.0 \%$ had inadequate level, $30 \%$ of mothers had moderate level in the pre -test knowledge. In the post-test knowledge level, majority of mothers $57.5 \%$ had moderate and $42.5 \%$ of mothers had adequate knowledge. The $X^{2}$ values is 48.46 at the $5 \%$ level of significant. These findings are consistent with the findings of Soosamma PV(1999) [18], Valsa(20001) [19], who reported that SIM was effective teaching strategy in terms of increasing the knowledge of the subject under study.

Aspect wise the pre-test and post - test score in definition, types and causes of diarrhea were $38.2 \%$ and $66.8 \%$ respectively, in the aspect of sign-symptoms and complication were $45.4 \%$ and $78.6 \%$, in home management of diarrhea were $51.1 \%$ and $72.5 \%$, in preventive measures were $52.5 \%$ and $77.5 \%$. The post -test mean knowledge enhancement was $28.6 \%$ with a paired't' value of 12.14 in the aspect of definition, types and causes of diarrhea. The post-test mean knowledge enhancement was $33.2 \%$ with a paired ' $t$ ' value of 9.05 in the aspect 
of sign-symptoms and complication. The post test mean knowledge enhancement was $21.4 \%$ with a paired't' value of 11.77 in the aspect of in home management of diarrhea. The post test mean knowledge enhancement was 25\% with a paired ' $t$ ' value of 9.41 in the aspect of preventive measures of diarrhea. In present study, existing knowledge of mothers in different aspect of diarrhea is inadequate. In similar study, by Kour A et al found only $30 \%$ provide home remedies and $25 \%$ are aware of ORT [20]. Geeta Parwanda et al found inadequate knowledge (9.38) and practice (8.98) of mothers regarding home management of diarrhea [21]. In a study by Priti Chaudhury et al found only $42 \%$ of mothers have knowledge regarding ORS preparation [22]. Manijeh et al, reported only $3.7 \%$ of good knowledge and $2.3 \%$ of good practice regarding diarrhea [23].

An association of selected demographic variables in relation to their knowledge was studied using Chi-square test. There was no significant association between variables like age, religion, and type of family, educational status, occupation, and number of children, family income, with pre-test knowledge scores except educational status of mother and residence of place in post test.

\section{CONCLUSION}

The present study was aimed to assess the effectiveness of the self-instructional module on knowledge of mothers regarding home management of diarrhea. There was a lack of knowledge among mothers in aspect of home management of diarrhea. The self-instructional module on "home management of diarrhea" was found to be effective in terms of increasing knowledge. There was no significant association between variables like age, religion, and type of family, educational status, occupation, and number of children, family income, with pretest knowledge scores.

\section{ACKNOWLEDGEM ENT}

All subjects who participated in the study are gratefully acknowledged. The Author is highly thankful to the authorities of hospitals.

\section{REFERENCES}

[1]. Parthasarathy A, menon PSN, Gupta Piyush, Nair MKC. IAP Textbook of Pediatrics. $5^{\text {th }}$ ed. Jaypee $5^{\text {nd }}$ ed. New Delhi: Jaypee brothers Medical Publishers(p)LTD. New Delhi.p-492

[2]. Global health observatory data. www.who.int/gho/ child-health/mortality/-under-five-text/ten/

[3]. India has highest incidence of diarrheal deaths: study (m.timesofindia.com/india/India... incidence...)

[4]. UNICEF data. M onitoring the situation of children and women. Progress report 2013. data.unicef.org/ ... diarrhea-disease.html

[5]. Subitha lakshminarayana, Ramakrishan Jayalakshmy. Diarreal disease among children in India:Current scenario and future perspectives." JNat Sci Biol Med.2015 Jan-Jun;6(1):24-28.

[6]. Jacob John, Rajiv sarkar, Gagandeep Kang. Rotavirus gastroenteritis in India, 2011-2013: Revised estimates of diseases burden and potential impact of vaccine. ScienceDirecct, 2014;32:A5-A9.

[7]. Tambe M. Diarrheal Diseases in children, A survey in the rural areas of Bellary District. India Journal of preventive and social medicine 1992;23(2)3336.

[8]. Sudarshan M.K. An epidemiological survey of diarrhea among children in the Karnataka region of Kaberi Basin" Indian Journal of Community Medicine. 1995;20;1-4.

[9]. M rudala K.Lala. Identification of causes of children(0-5years) death in Distict Ahmedabad (Gujarat). India Journal of Maternal and child health 1999; 10(2).

[10]. Wong L Donna. Nursing care of Infant and Children. $5^{\text {th }}$ ed. Mosby, 1995; p.1231

[11]. Diarrhea, Dehydration \& Rehydration. (rehydrate .org/dehydrat/)

[12]. Ray S.K. Utilization OF ORS during Diarrhea in three districts of West Bengal. Indian Journal of Public Health. 1994:38:73-76.

[13]. Nettina M. Sandra. Lippincott M anual of Nursing Practice. $8^{\text {th }}$ ed. Jaypee brothers Medical Publishers(p) Ltd: 2006; p.1554.

[14]. Olango P., Aboud F. Determinants of mother's treatment of diarrhea in rural Ethiopia. Soc. Sci.Med. 1990;31(11):1245-9.

[15]. Sing],Gowriswari D, Chavan BR, Patiat RA, Debnath $A C$, Jain DC, et al. Diarrheal diseases amongst children under five. A study in rural Alwar. J Commun.Dis. 1992;24:150-5.

[16]. Black RE, Lopez De Romana G, Brown KH, Bravo N, Bazalar OG, Kanashio HC. Incidence and etiology of infantile diarrhea and major routes of transmission in Huascar, Peru. Am J Epidemiol. 1989;129(4):783-185.

[17]. Park K, Park's Text Book of Preventive and Social $M$ edicine. $23^{\text {th }}$ ed. M/s BANARSIDAS BHANOT PUBLISHERS Jabal pur, 2015 p 228.

[18]. Soosamma PV. Preparation of a Self-instructional of selected drugs to children and to determine its effectiveness. (Unpublished Master Dissertation, Rajiv Gandhi University of Health Sciences, Bangalore 1999). 

of Under Five Children in Selected Hospital at Bangalore.

[19]. Valsa P.J. A study to determine the effectiveness of Self-instructional Module for staff nurses on phototherapy for neonatal jaundice. (Unpublished Master Dissertation, Rajiv Gandhi University of Health Sciences, Bangalore 1995).

[20]. Kour A, chowdhury S, Kumar R. M other's beliefs \& practices regarding prevention \& managementof diarrhea disease. Indian Pediatric 1994;31(1)557.

[21].Geeta Parwanda, Namita Batra, Neeraj, Amit. Knowledge and practice of mothers regarding home based management of diarrhea." Indian journal of public health Research and Development 2015;6(4):77.
[22]. Priti Chaudhary, Saurav Basu, Anthony K Dzeyie, Sumit Gulla, Sujata Khade, Adarsh Patel, Debasis Phukan, Tanzin Dikid, Anil Kumar, Askash Shrivastava. Knowledge, attitude and practice of mothers regarding diarrheal illness in children under five years of age: A cross Sectional study in an Urban Slum of Delhi, India. The Journal of communicable diseases 2014;46(3):13-21.

[23]. M anijeh khalili, M aryam M irshahi, Amir Zarghami, M ohsen Rajabnia, Fatemeh Farahmand. M aternal knowledge and practice regarding childhood diarrhea and diet in Zahedan, Iran. Health Scope.2013 May;2(1):19-24.

How to cite this article:

Nirmali Gogoi. A Study to Assess the Effectiveness of Self-Instructional M odule on Home Management of Diarrhea among M others of Under Five Children in Selected Hospital at Bangalore. Int J Intg M ed Sci 2016;3(8):397402. DOI: 10.16965/ijims.2016.146 